\author{
Monika Krajewska \\ Uniwersytet Mikołaja Kopernika w Toruniu \\ monika.krajewska@umk.pl
}

\title{
OD DESKI DO DESKI: PARATEKSTY Z PERSPEKTYWY ORYGINAŁU I PRZEKŁADU*
}

DOl: http://dx.doi.org/10.12775/RP.2019.013

Zarys treści: Niniejszy artykuł dotyczy paratekstów graficznych, a zagadnienie to rozpatrywane jest z perspektywy oryginału i przekładu. W pierwszej części artykułu uwagę skupiono na okładkach tekstów wyjściowych i konsekwencjach związanych z odmienną koncepcją szaty graficznej tekstów docelowych, w tym innym sektorze projektowanych odbiorców i potrzebie wprowadzenia dodatkowych komentarzy odtranslatorskich. W drugiej części podjęto temat ilustracji oraz ich roli w tekście źródłowym, od niej bowiem zależy ocena stosowanych procedur przekładowych - redukcji, modyfikacji i przeniesienia.

Słowa kluczowe: paratekst, oryginał, przekład, tłumaczenie, szata graficzna, okładka, odbiorca, komentarz odtranslatorski

„Paratekst: to [coś] ${ }^{1}$, dzięki czemu tekst staje się książką i jako książka trafia do czytelnika, czy też ogólniej do publiczności” (za: Skibińska 2011: 179) zauważa Gérard Genette. Elżbieta Skibińska, powołując się na francuskiego badacza, pisze że parateksty

nie są tylko zwykłymi „uzupełnieniami” umieszczonymi wokół tekstu, nie są też tylko swego rodzaju „strefą przejściową” między tekstem, a tym, co nim nie jest. Stanowią one miejsce „transakcji”, w którym realizuje się pewna strategia oddzia-

* Trzonem artykułu jest część rozważań przedstawionych w rozdziale „Parę słów o paraktekstach” wchodzącym w skład książki „Oswoić słowo. Komentarze w północnych książkach Mariusza Wilka" (Krajewska 2017). Rozważania na potrzeby artykułu zostały jednak rozszerzone, uzupełnione i uaktualnione, a wnioski wyprowadzone z uwzględnieniem nowych ustaleń.

1 Komentarze umieszczone w nawiasach kwadratowych moje - M.K. 
ływania na odbiorcę, mająca prowadzić do „dobrego przyjęcia tekstu i jego lektury właściwej, czyli takiej, jaką zakłada autor i jego sprzymierzeńcy” (ibid.).

Elementy, które znajdują się poza tomem zawierającym tekst główny, wychodzą poza obręb danej książki nazywane są epitekstami. Należą do nich m.in. omówienia w katalogach wydawniczych, biogramy, recenzje, spisy innych publikacji wydawnictwa oraz autora dzieła zamieszczone, publikacje na temat utworu zamieszczane w prasie, radiu, telewizji, Internecie (Loewe 2007: 224). Wszystkie elementy mieszczące się w sferze wyznaczonej przez okładkę (tytułowe deski) wraz elementami ją tworzącymi nazywane są z kolei perytekstami i to one będą przedmiotem niniejszego artykułu. Kluczowym miejscem wspomnianej przez Gérarda Genette’a transakcji jest właśnie okładka książki. Wybór ilustracji, tekstu na okładkę, a nawet nakład i sposób dystrybucji są jak podkreśla Adriana Sara Jastrzębska (2011: 323) - istotnym komunikatem. Iwona Loewe przyrównuje okładkę do ulotki, która „służyć ma informowaniu i rekomendacji, czyniąc z utworu produkt” (2007: 86).

Pierwsza strona okładki, najczęściej na tle występującego elementu niewerbalnego (ilustracji), zawiera imię i nazwisko autora (sporadycznie tylko imię lub pseudonim) oraz tytuł. Niekiedy pojawiają się też inne elementy, np. logo wydawnictwa, nazwa gatunku. Zazwyczaj już pierwsza strona okładki buduje nasz stosunek do danej książki. Badając pod tym względem oryginał i przekład, możemy zaobserwować różnice w recepcji konkretnego produktu.

Na wstępie odwołam do rozważań Marty Kaźmierczak (2016), która przeanalizowała powieści Borisa Akunina o detektywie Fandorinie. Cykl „Приключения Эраста Фандорина”, zwany także „Новый детективъ”, ukazuje się w Rosji od 1998 r. Dwadzieścia lat później, po trzyletniej przerwie, pojawiła się kolejna, szesnasta odsłona przygód Fandorina. Tytuł „He прощаюсь” daje czytelnikom nadzieję na kontynuację historii detektywa (polski przekład „Nie żegnam się” również został opublikowany w 2018 r.), choć sam autor określił książkę jako ostatnią z serii (zob. Akunin 2017). We współczesnej Rosji - jak podkreśla wspomniana badaczka -

zapanowała prawdziwa moda na „projekty” w sferze kultury, jednak w przypadku Borisa Akunina określenie to bynajmniej nie sprowadza się do aspektu handlowego i reklamowego, zaś deklarowany przez autora zamiar pisania książek przerzucających pomost między literaturą popularną a wysoką nie pozostaje gołosłowny. Autorskie parateksty werbalne dyskretnie podpowiadają kierunki interpretacji wykraczającej poza lekturę warstwy przygodowo-sensacyjnej, wskazują źródła inspiracji i literackie powinowactwa (Kaźmierczak 2016: 62). 
Nie mniej ważne - podkreśla Kaźmierczak - są jednak dla Akunina elementy graficzne. Cykl (publikowany przez oficynę Zacharow) jest spójny od pierwszej jego części elegancką czarno-białą okładkę zdobią kolaże, których autorem jest Max Ernst (wykorzystane prace pochodzą z albumu Ernsta „Tydzień dobroci lub Siedem głównych żywiołów”, 1934 r.).

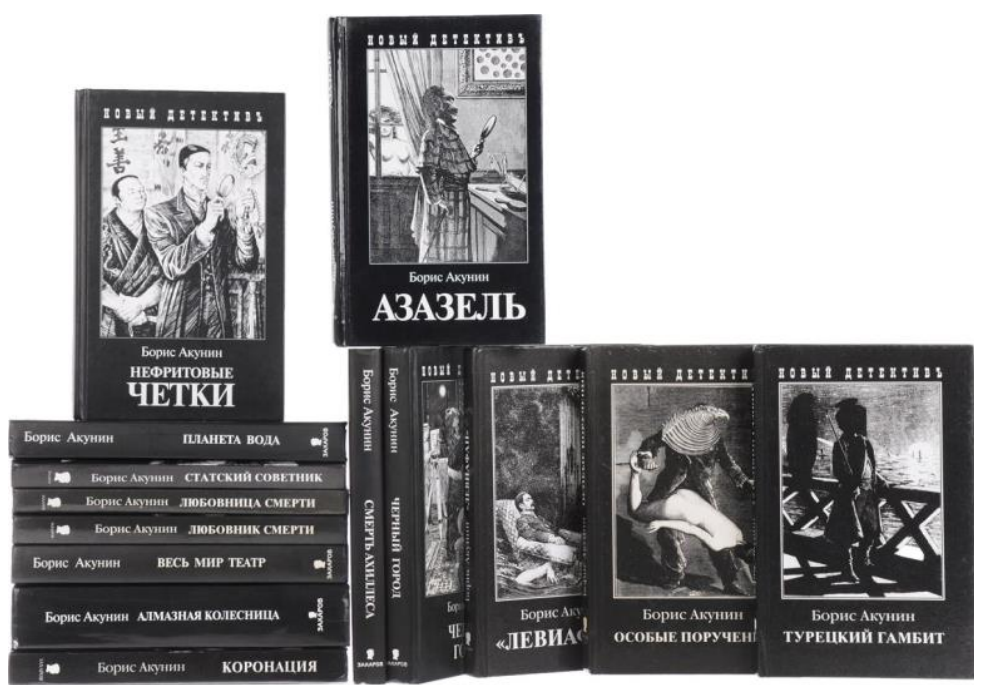

Борис Акунин: „Приключения Эраста Фандорина” /комплект из 14 книг/ (fot. za: https://www.ozon.ru/context/detail/id/142466019/ dostęp: 15.04.2019).

Na polskim rynku przygody detektywa doczekały się kilku wersji szaty graficznej, które według Kaźmierczak umownie można nazwać serią z szachownicą (2003-2005), serią białą (2009-2012?) i serią z ramką (od 2014).

Okładki pierwszej serii nawiązują do estetyki proponowanej przez oficynę Zacharow włącznie z przebiegającym u góry czarnym pasem ze złożonymi białą czcionką nazwiskiem autora i tytułem [...]. Zasadniczą przestrzeń zajmuje natomiast reprodukcja jakiegoś dzieła malarskiego, którą częściowo przysłania fragmentaryczny wzór szachownicy. Odwołanie do szachów wydaje się nader stosowne, [...] mamy przecież do czynienia z kryminałem, a zatem łamigłówką [...] (ibid.: 62). 


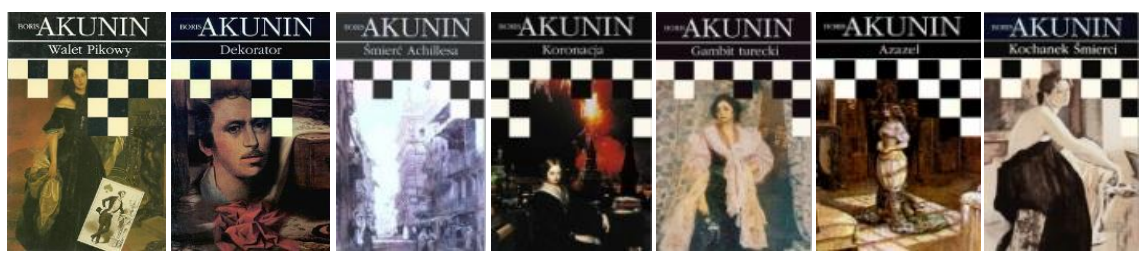

Przykładowe okładki - Boris Akunin: „Walet pikowy”, „Dekorator”, „Śmierć Achillesa”, „Koronacja”, „Gambit turecki”, „Azazel”, „Kochanek śmierci” (fot. za: https://dobroczynny. $\mathrm{pl} /$ szukaj? controller=search\&orderby=position\&orderway=desc\&search_query=akunin\&submit_search=; dostęp: 15.04.2019).

Mimo braku troski o spójność elementu wizualnego z tekstem (niejednokrotnie podsuwające mylne tropy), co wskazuje na nieprzyznawanie w wydaniach z lat 2003-2005 ilustracjom na okładce funkcji komunikacyjnej, a wyłącznie zdobniczej i afektywnej, wykorzystanie materiału ikonograficznego - jak podsumowuje wymieniona wyżej badaczka - konotuje jednak przynależność danej książki do literatury wysokiej lub jej pogranicza, co jest zgodne $\mathrm{z}$ intencjami autora (zob. ibid.: 76).

Druga seria cyklu charakteryzuje się białym tłem i jednokolorowym rysunkiem przedstawiającym rekwizyt bądź detal anatomiczny w dużym powiększeniu. Obecność danego elementu może mieć bezpośredni związek z treścią utworu, niekiedy jednak wydaje się przypadkowa (zob. ibid.: 76). Całość dopełnia czarne liternictwo. Seria, tj. tomy, które ukazały się w takim wydaniu, przez swój minimalistyczny, uporządkowany wygląd w dalszym ciągu mogą realizować zamierzenia autora oryginału.

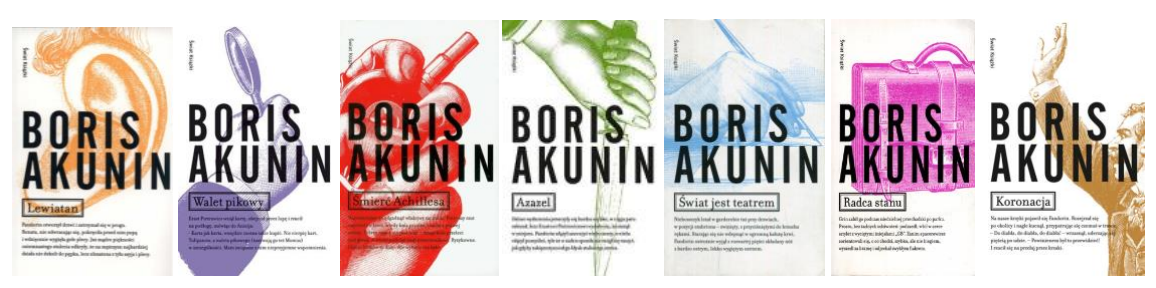

Przykładowe okładki - Boris Akunin: „Walet pikowy”, „Lewiatan” (fot. za: https://allegro. pl/oferta/walet-pikowylewiatan-7979727559), „Śmierć Achillesa”, „Azazel”, „Świat jest teatrem" (fot. za: https://www.empik.com/szukaj/produkt?author=akunin+boris\&sort=scoreDesc), „Radca stanu” (fot. za: https://polter.pl/ksiazki/Radca-stanu-n34270), „Koronacja” (fot. za: https://kobieta.interia.pl/zycie-i-styl/news-boris-akunin-koronacja,nId,430352; dostęp: 15.04.2019). 
Zupełnie inaczej ma się rzecz w przypadku serii najnowszej, gdzie przesunięcia recepcyjne i zmiana projektowanego odbiorcy są zdecydowanie najbardziej widoczne:

Tu kolorowy rysunek o wyraźnym konturze, uprzywilejowujący postaci pięknych kobiet budzi skojarzenia z powieścią przygodową oraz kostiumowym romansem. Wizualnie zakodowana sugestia gatunkowa różni się od wcześniejszych i podpowiada czytelnikom określone style odbioru, przy czym bynajmniej nie uczula na obecność innych - poza sensacyjną - warstw narracji. Ale też najwyraźniej modelowy czytelnik/potencjalny nabywca jest tu profilowany inaczej, mniej ambitnie niż w przypadku stonowanych wydań oficyny Zacharow, a także wysmakowanej estetycznie pierwszej serii wydawniczej Świata Książki (ibid.: 77).
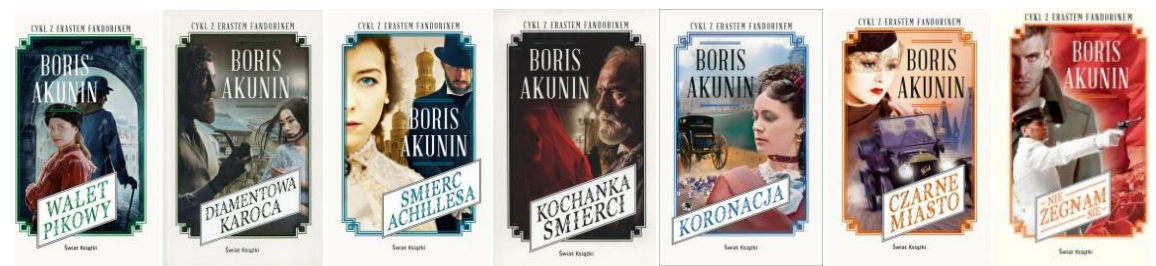

Przykładowe okładki - Boris Akunin: „Walet pikowy”, „Diamentowa karoca”, „Śmierć Achillesa”, „Kochanka śmierci”, „Koronacja”, „Czarne miasto”, „Nie żegnam się” (fot. za: https:// www.znak.com.pl/autor/Boris-Akunin; dostęp: 15.04.2019).

Już na podstawie tego krótkiego przeglądu można stwierdzić, że na polskim rynku, mimo że wszystkie tłumaczenia wydane zostały przez Świat Książki, panuje okładkowy chaos. Żadna z serii nie funkcjonuje w całości niektóre z tomów ukazały się aż w trzech wersjach, inne w dwóch bądź jednej. Takie podejście może dezorientować czytelnika lub budzić frustrację tych, którzy chcieliby zgromadzić cały cykl w jednej szacie graficznej (zob. ibid. 78). Największe szanse na to są w przypadku serii z ramką, w której ukazały się ostatnie tłumaczenia oraz większość wznowień. Wydaje się więc, że i w odniesieniu do polskich wydań (gdy w serii z ramką ukaże się cały cykl) będzie można mówić o przemyślanym konsekwentnym działaniu, choć punkt ciężkości jest tu wyraźnie przesunięty w kierunku odbiorcy kultury masowej.

W tym miejscu, kontynuując temat szaty graficznej okładek i serii wydawniczej jednocześnie, chciałabym przejść do północnego cyklu Mariusza Wilka. Przez ponad dwie dekady autor mieszkał na północy Rosji, Rosji tej doświadczał, a następnie przelewał na papier. Przelewał, jak wiedzą wszyscy 
ci, którzy zetknęli się z jego pisarstwem, za pomocą mieszanki językowej języka polskiego z dużym udziałem rosyjskiego. Że była to mieszanka nie tylko językowa, ale i wybuchowa, mieliśmy okazję się przekonać po publikacji pierwszej książki ze wspomnianego cyklu, a mianowicie "Wilczego notesu”. Rozgorzał wtedy spór publiczny, w którym zmierzyli się na słowa m.in. Jerzy Pilch jako oskarżyciel i Stanisław Lem jako obrońca. W niniejszym artykule jednak nie na słowach (stylu pisarza), a na elementach graficznych chcę się skupić.

Większość północnych książek Mariusza Wilka wydała Oficyna Literacka Noir sur Blanc $c^{2}$, stąd szata tych wydań ma analogiczny charakter, każda kolejna publikacja powtarza przyjęty wcześniej schemat (czcionka, rozmieszczenie poszczególnych elementów) $)^{3}$. W serii nie ukazała się tylko „Wołoka”, wydrukowana przez Wydawnictwo Literackie (2006). Natomiast pierwsza północna książka „Wilczy notes” początkowo sygnowana była przez słowo/ obraz terytoria (wyd. I: 1998, wyd. II: 2003), a następnie już przez Oficynę (2007).

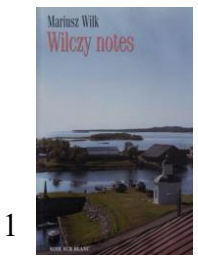

2

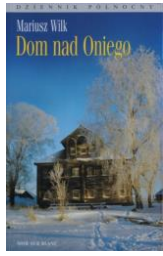

3

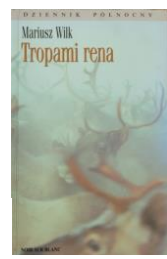

4

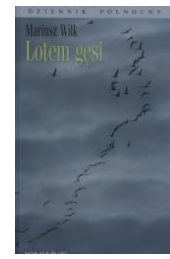

5

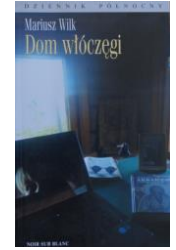

Okładkę „Wilczego notesu” /1/ zdobi fotografia Władysława Wisłowskiego przedstawiająca Wyspy Sołowieckie - co stanowi bezpośrednie nawiązanie do treści utworu. W przypadku pozostałych książek zdjęcie jest odbiciem tytułu i te dwa elementy ściśle ze sobą współgrają, odzwierciedlając jednocześnie wnętrze dziennika.

2 W Oficynie Noir sur Blanc jako pierwszy ukazał się utwór „Dom nad Oniego (2006), wcześniej (w 1999 roku) przez Les Éditions Noir sur Blanc zostało opublikowane francuskie tłumaczenie „Wilczego notesu”: „Le journal d'un loup”, tłum. Laurence Dyevre.

${ }^{3}$ Należy zauważyć, że ten typ okładki nie jest tylko zarezerwowany dla książek Mariusza Wilka, to samo liternictwo i porządek elementów charakteryzuje też inne publikacje, m.in. Nicolasa Bouviera (np. https://www.noir.pl/ksiazka/603/Nicolas-Bouvier-Oswajanie-swiata), André Brinka (https://www.noir.pl/ksiazka/490/Andr\%C3\%A9-Brink-Zanim-zapomne), Jeana Echenoza (np. https://www.noir.pl/ksiazka/435/Jean-Echenoz-Odchodze;), Franceski Michalskiej (https://www.noir.pl/ksiazka/403/_Ca\%C5\%82a\%20rado\%C5\%9B\%C4\%87\%20 \%C5\%BCycia; dostęp: 15.04.2019). 
Lekturę „Domu nad Oniego” /2/ otwierają m.in. poniższe słowa:

Po dziesięciu latach życia pod kręgiem polarnym przeniosłem się z Wysp Sołowieckich na Morzu Białym do wsi Konda Biereżnaja nad Jeziorem Onieżskim i osiadłem w starym drewnianym domu [...] (Wilk 2006: 13).

W moim kondobiereżskim domu nikt nie zimował od ponad pięćdziesięciu lat (sam dom pochodzi z początku ubiegłego wieku) (ibid.: 39).

Właśnie ten dom uchwycony w pięknej zimowej scenerii przez żonę pisarza, Natalię Wilk, znalazł się na okładce. „Dom nad Oniego” inicjuje fasada budynku, ostatnia zaś z analizowanych książek, „Dom włóczęgi”/5/, już od samego początku zdaje się zapraszać czytelnika do środka. Każdą bowiem podróż pisarz zaczyna w tym domu i w nim kończy (zob. Wilk 2014a: 124), a konkretnie przy swoim stole (por. ibid.: 124). Na tym stole, uwiecznionym zresztą przez samego autora ${ }^{4}$, znajduje się laptop, z ekranu zaś gdzieś w bok spoglądają oczy dziewczynki, córki pisarza. Są one ważnym sygnałem, gdyż „tym razem Wilcza włóczęga wiedzie tropą wyznaczoną zdziwieniem dostrzeżonym w oczach Martuszy" (fragment zapowiedzi zawartej na skrzydełkach okładki).

W przestrzeni chronologicznej wyznaczonej przez oba domy - „Dom nad Oniego” i „Dom włóczęgi” - znajdują się dwie książki, tytuły których odnoszą się do świata przyrody: „Tropami rena”/3/ i „Lotem gęsi” /4/. Na okładce pierwszej widzimy rozbielone jakby mgłą tytułowe reny (do tej okładki jeszcze wrócę), na okładce drugiej - klucz ptaków. Autorem fotografii przedstawiającej szare niebo przecięte kluczem ptaków jest Witalij Nakonieczny ${ }^{5}$, artysta odpowiedzialny za szatę graficzną ponad trzystu książek i albumów. Twierdzi on, że ilustrator jest poniekąd współautorem książki, a stworzona przezeń obudowa powinna pomóc czytelnikowi przeniknąć w podtekst utworu, wskazać tajny kod pisarza (Zob. Zhemoytelite, Nakonechnyy 2012). Fotografia Nakoniecznego wzmacnia brzmienie tytułu i staje się obrazem dla słów:

${ }^{4}$ Mariusz Wilk w rozmowie telefonicznej (8.05.2019) zwrócił uwagę, że żaden element, który widnieje na fotografii zdobiącej okładkę (w tym zdjęcie przedstawiające Jerzego Giedroycia, figurka Buddy, różaniec z Tyńca, książka o protopopie Awwakumie) nie znalazł się tam przypadkowo.

${ }^{5}$ W 1972 roku artysta pojechał do Karelii na kilka dni (w związku z pierwszym poważnym zleceniem), a został tam na całe życie (zob. Zhemoytelite, Nakonechnyy 2012). Jest laureatem m.in. nagrody SAMPO, przyznawanej przez Naczelnika Karelii (zob. Leonardo... 2019). 
Pierwsze dzikie gęsie lecą na południe. Najpierw usłyszałem tęskny klangor wysoko w niebie, potem wpatrując się ujrzałem dwa klucze. Chciałoby się z nimi ulecieć na Krym i powrócić tu wiosną. Żyć rytmem przelotnych ptaków: jesienią na południe, wiosną na północ (Wilk 2012a: 183); jak myślisz, dzikie gęsi to podróżnicy czy tubylcy? Jeśli tubylcy, to gdzie ich ojczyzna? (ibid.:197); Czas [w Zaonieżu] krąży jak dzikie gęsi nad głową, jesienią odlatują, wiosną przylatują, a nie biegnie zaś bez sensu po linii donikąd (ibid.:169-170).

Na gruncie rosyjskim, z wyjątkiem „Wilczego notesu” (wydanego w Moskwie przez Новое литературное обозрение), dzienniki pisarza publikuje jedna oficyna - wydawnictwo Iwana Limbacha $z$ Petersburga. W obrębie tych wydań mamy do czynienia z jednolitą koncepcją graficzną, za którą odpowiedzialny jest Nikołaj Tiepłow.

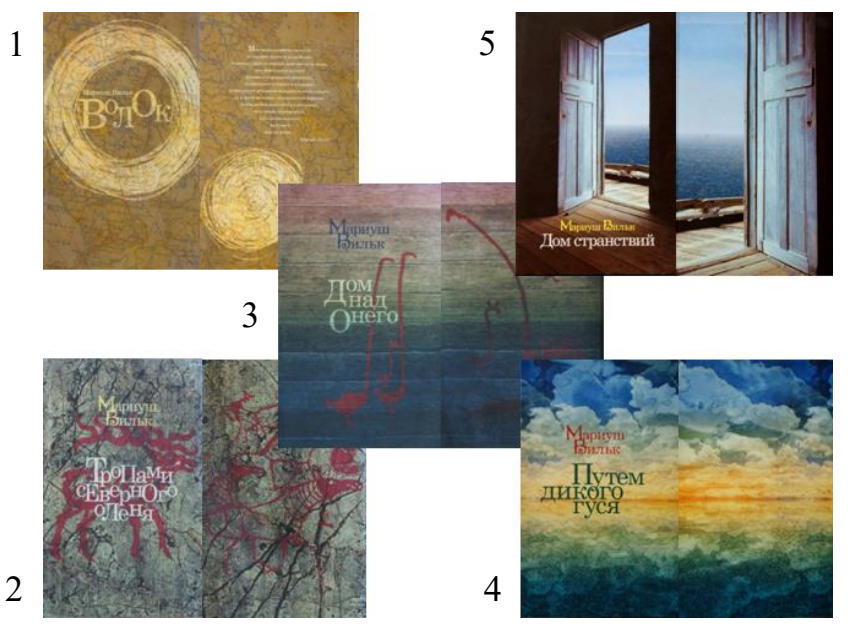

Już pierwszy rzut oka na okładki Tiepowa skłania do refleksji na temat ich symbolicznego charakteru. Nawiązują one jednak do treści poszczególnych etapów tropy Wilka: mapa w „Wołoce” /1: «Волок»/, dom (deski), i jezioro (deski zabarwione na zielonkawo i niebiesko, ptactwo wodne) w „Domu nad Oniego” /3: «Дом над Онего»/, w „Domu włóczęgi” /5: «Дом странствий»/ - drewniana podłoga przez otwarte drzwi płynnie przechodząca w drewnianą platformę, za nią przestrzeń wody i nieba (co koresponduje ze słowami „Nasz 
dom [...] stoi zadem do drogi i fasadą na zachód w stronę Oniego, zatopiony we własnych myślach"; Wilk 2014a: 126). Wśród różnych wątków budujących tom „Tropami rena” /2: «Тропами северного оленя»/, obok podążania za tytułowymi renami, jest również przyglądanie się naskalnym rysunkom:

ryty na skałach Biesow Nosa wybite kwarcowym dłutem mają ponad siedem tysięcy lat (Wilk 2007a: 17); Nadia nauczyła mnie, jak czytać naskalne pisma Saamów: gdzie wodą zwilżyć skałę, by rysunek wyszedł, gdzie zasłonić czarną błoną, aby światło padło skośnie, a gdzie lustro wstawić (ibid.: 16).

Swoistym lustrem odbijającym naskalne rysunki jest okładka zdobiąca tekst docelowy. Gęsi na okładce rosyjskiego przekładu „Lotem gęsi” /4: «Путем дикого гуся»/ nie widać, za to można dostrzec granatowe niebo i chmury („ojczyzną [gęsi] jest powietrze, niebo”; Wilk 2012a: 197), pas horyzontu oznaczony ciepłym kolorem („na Południe odlatują, żeby przezimować w cieple”; ibid.: 197), odbicie nieba w cieplejszych odcieniach wody („Żyć rytmem dzikich łabędzi to wzbijać się tak wysoko, aby z Północy widzieć Południe, a z Południa - Północ"; ibid.: 198). Warto podkreślić, że okładki Tiepłowa są nie tylko estetyczne i spójne koncepcyjnie, ale też - jak można było się przekonać - trafne pod względem treści.

Po przeglądzie książek wydanych przez Noir sur Blanc i Wydawnictwo Iwana Limbacha chcę wrócić do pytania o odbiorcę oryginału i przekładu. $\mathrm{Z}$ założenia wiemy, że nie stoi on na tej samej pozycji, a różnice w wiedzy wyrównuje się często za pomocą przypisów - paratekstów odtranslatorskich, jednak zazwyczaj potrzeba dodatkowych wyjaśnień nie wynika z odmienności okładek. A tak właśnie jest w tym przypadku. Aby jednak nasz przegląd był pełen, musimy polskie wydania odwrócić na drugą stronę: czytelnik, sięgnąwszy po oryginał, otrzyma nie tylko fotografię, która odzwierciedla zawartość książki, ale też - na czwartej stronie okładki - fotografię przedstawiającą autora („Wilczy notes” /1/, „Tropami rena”/3/, „Dom włóczęgi”/5/), autora wraz z żoną (w zadedykowanym żonie „Domu nad Oniego” $/ 2 /$ ), autora wraz z żoną i córką („Lotem gęsi” /4/). Biorąc do ręki „Lotem gęsi”, czytelnik zobaczy niewielki wycinek Zaonieża i troje jego mieszkańców, których utrwalił Władimir Szraga ${ }^{6}$. To samo tło, co na zdjęciu Boczarowa /2/, jednak

${ }^{6}$ Więcej na temat autora na jego stronie: http://shraga.ru/ (dostęp: 15.04.2019). Konda Biereżna i dom Wilka w obiektywie Szragi (lipiec-sierpień 2011): http://motoknitok.livejournal. com/147818.html (dostęp: 15.04.2019). Warto dodać, że Władimir Szraga sam stał się jednym z bohaterów dziennika Mariusza Wilka: „[...], a my z piterskim fotografem Władimirem Szragą 
inni bohaterowie - już nie mąż i żona, tylko mama i papa (jak mówi o sobie Wilk), a między nimi - córka (choć często w ustach autora będzie to doczka $a^{7}$ ).
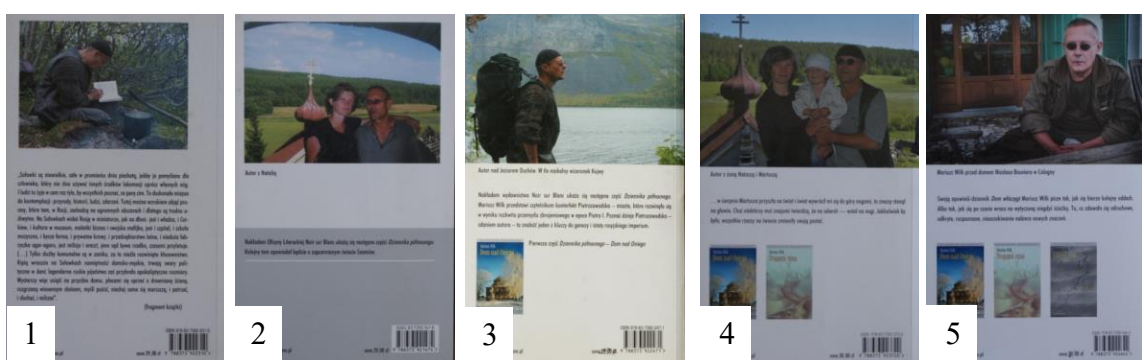

Odbiorca nim zacznie czytać - już wie, kto towarzyszy pisarzowi na danym etapie życia, a jemu - czytelnikowi - towarzyszyć będzie podczas lektury. Powyższe parateksty graficzno-werbalne w subtelny, nienarzucający się sposób przygotowują czytelnika do wejścia w tekst. Pozbawiony takiej wiedzy odbiorca przekładu otrzymuje ją w postaci wyjaśnień odtranslatorskich: żona Mariusza Wilka (жена Мариуша Вилька; Wilk 2010: 14), Żona M. Wilka (Жена М. Вилька; Wilk 2014b: 62), Natasza - żona, Martusza - córka M. Wilka (Наташа - жена, Мартуша - дочь М. Вилька; Wilk 2015: 12). A zatem to, со dzieje się poniekąd nieświadomie w przypadku odbiorcy oryginału, w przekładzie przybiera formę nie tylko bardziej zauważalną, ale też mogącą budzić irytację (należy tu dodać, że nadgorliwość nie zawsze musi odnosić się do tłumacza, za nim stoi jeszcze redaktor). Jedna z rosyjskich czytelniczek odnotowuje:

[...] в книге очень много ссылок, относительно любого упоминаемого персонажа дается объяснение, кто это такой и чем знаменит. Даже отдельной сноской объяснили, что Наташа - это жена Мариуша Вилька ${ }^{8}$ (ValSi 2014).

idziemy do czasowni, aby Wład mógł zdjąć to światło w pustym chramie. Przed dziesiątą słońce wpada na parę minut przez okno i oświetla krzyż, który ongiś tu przyniosłem na plecach ze wsi Wigowo. Mamy zatem chwilę na zdjęcie tego światła z krzyża. Wreszcie słońce gaśnie w Oniego między banią Pieczugina a krzakiem bzu, Szraga wyłazi na dzwonnicę, aby stamtąd łapać brzask [...]” (Wilk 2014a: 48). Później jeszcze raz Wilk wraca do tego obrazu: „Tak, tak, trzeba wiedzieć - jak widzieć! Gdzie należy spojrzeć i kiedy oglądać, przy jakim oświetleniu, z którego kąta i tak dalej. Weźmy dla przykładu to zdjęcie w czasowni, Szraga był w Kondzie po raz pierwszy, skąd miałby wiedzieć, że słońce rzuca piętno światła na krzyż jedynie w białe noce na parę minut przed dziesiątą?" (ibid.: 58).

7 „[...] słowo docz (doczka) traktuję na równi z córką (córeczką), gdyż moja Martusza jest pół Polką, a na poły Rosjanką [...]" (Wilk 2014a:14).

${ }^{8}$ „W książce jest bardzo dużo przypisów, przy każdej wspomnianej postaci pojawia się wy- 
Oczywiście dla każdego przypisu można znaleźć wytłumaczenie: czasem nieco na wyrost, jak np. kilkakrotne pojawienie się w dość bliskim sąsiedztwie imienia Natasza, raz w odniesieniu do żony, raz w odniesieniu do badaczki Nataszy Jegorowej (Wilk 2012a: 42), innym razem zdecydowanie poważniejsze, jak w przypadku innej kolejności publikacji w języku rosyjskim9.

W ostatniej północnej książce Wilka, dedykowanej Martuszy (tam, gdzie tłumaczka wyjaśnia, że Natasza to żona, a Martusza to córka M. Wilka), odbiorca oryginału ma szansę dostrzec twarz dziewczynki na ekranie laptopa widniejącego na okładce, na skrzydełkach zaś doczyta:

W domu nad Oniego nastąpiły zmiany. Pojawił się ktoś, kto sprawił, że Wilk na nowo czyta alfabet natury, a własną biografię tłumaczy na nieznane mu wcześniej emocje. [...] Tym razem wilcza włóczęga wiedzie tropą wyznaczaną zdziwieniem dostrzeżonym w oczach Martuszy (Wilk 2014a: przednie skrzydełko).

oraz

W 2009 roku przyszła na świat jego córka, Marta Matylda (ibid.: skrzydełko tylne).

Ze względu na inną koncepcję okładek publikacji rosyjskich wiemy już, że fotografii nie zobaczymy, szkoda jednak, że nie wykorzystane zostały wspomniane właśnie skrzydełka, których przestrzeń mogłaby posłużyć zniwelowaniu tego typu nierówności. Ta część okładki, tylko w kilku przypadkach zagospodarowana przez fragmenty książek, mogłaby odgrywać ważniejszą rolę (tu zaś mamy do czynienia z powieleniem nie fragmentu tekstu a całej notatki: to samo zdjęcie przedstawiające Mariusza Wilka oraz ta sama informacja o nim pojawia się zarówno w tomie «Тропами северного оленя», jak i w tomie «Дом над Онего»).

jaśnienie - kim jest i czym się wyróżniła. Nawet w odrębnym przypisie wyjaśniono, że Natasza to żona Mariusza Wilka" [tłum. M.K].

${ }^{9}$ W języku rosyjskim utwór „Тропами северного оленя” (2010) ukazał się wcześniej niż „Дом над Онего” (2012). 


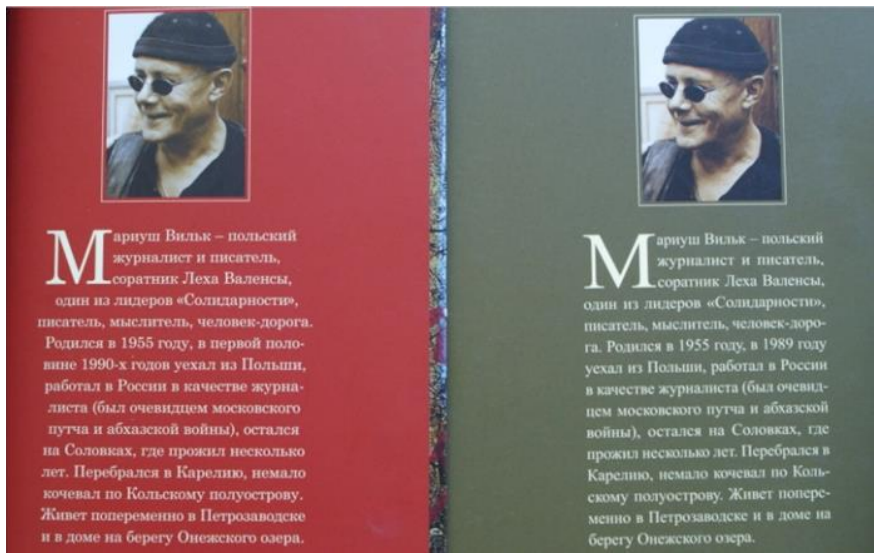

O ile relację okładka oryginału - okładka przekładu można byłoby choć częściowo uratować dzięki skrzydełkom, o tyle nie ma już na to szans w przypadku relacji tekst - okładka, co dotyczy książki „Tropami rena”. Pod datą 13 kwietnia czytamy:

Julian Konstantinow podarował mi piękne zdjęcie renów, w sam raz na okładkę Tropami rena. Las rogów tworzy na zdjęciu przedziwną tropę w powietrzu... Na pierwszym planie jeszcze wyraźne łby i oczy reniferów, a dalej już tylko kłęby, karki i rogi, rogi - tropa rogów. Lecz przecież wystarczyłby okrzyk (wystrzał!), żeby to stado w panice się rozpierzchło, sama zaś tropa znikła. Jak sen, z którego nas znienacka wyrwano. Metafora mojej książki? Czyż nie tak samo zaczynałem tę wyprawę, pełen otuchy, że spotkam prawdziwych Saamów? Początkowo tropiłem szczegóły, szukając potwierdzenia dla tego, o czym wcześniej przeczytałem - wykoncypowanych tez, konstrukcji myślowych, Bóg wie czego. A w miarę upływu czasu dociera do mnie, że to tropa w powietrzu (Wilk 2007a: 76).

Powyższy opis nie daje stuprocentowej pewności obcowania $\mathrm{z}$ tą samą fotografią, której przyglądał się pisarz, jednak więź między przytoczonymi słowami i zdjęciem widniejącym na okładce wydaje się bardzo mocna. Prawdopodobnie więc tropę w powietrzu śledzimy na tym samym co pisarz zdjęciu. Możliwości współtowarzyszenia w odbiorze fotografii - ze względu na inną projekt - pozbawiony został czytelnik tekstu docelowego ${ }^{10}$.

${ }^{10} \mathrm{~W}$ odnośnym fragmencie przekładu zamiast tytułu danego utworu pojawia się „przyszła książka”. Przeczy to niestety refleksji autora, który przyrównuje fotografię do swojej obecnej wyprawy: „Metafora mojej książki? Czyż nie tak samo zaczynałem tę wyprawę, pełen otuchy, że spotkam prawdziwych Saamów?” Zdaje się, że w tym wypadku lepszym rozwiązaniem byłoby bądź opuszczenie fragmentu „w sam raz na okładkę Tropami rena”, bądź też tłumaczenie dosłowne. W przekładzie: „Юлиан Константинов подарил мне красивую фотографию с оленями - 

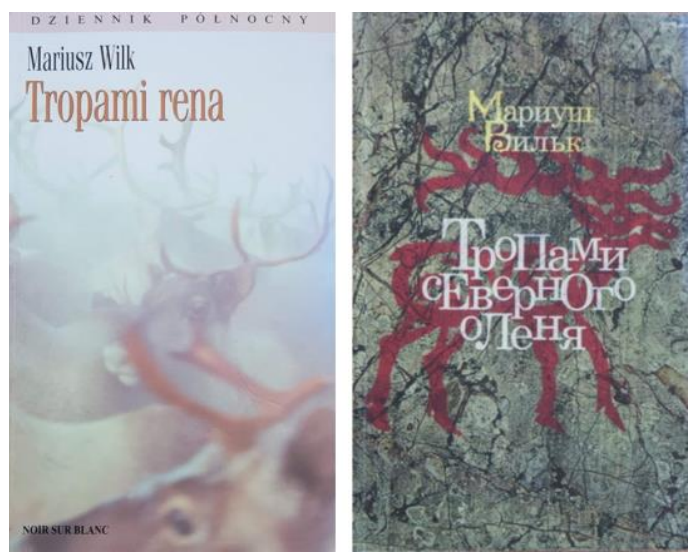

O ile można się zastanawiać nad niewykorzystaniem przestrzeni skrzydełek, o tyle w kontekście przedstawionej relacji sytuacja wydaje się bez wyjścia. Może gdyby cały północny cykl wydawany był jednocześnie, Nikołaj Tiepłow (bądź ktokolwiek inny) rozważyłby, choć to mało prawdopodobne, możliwość zmiany koncepcji graficznej, ale w przypadku cyklu tworzonego na bieżąco (powstanie oryginału - powstanie przekładu - publikacja), nikt raczej dla jednego wspomnienia nie odejdzie od założonego i realizowanego projektu.

Podsumowując rozważania dotyczące tytułowych desek, należy odnotować, że zmiana koncepcji okładki:

- może wiązać się bądź z odmienną recepcją gatunkową książki/książek (cykl „Przygody Erasta Fandorina”: seria z szachownicą vs seria z ramką), bądź z powiększaniem różnic między czytelnikiem $\mathrm{T}_{1} \mathrm{i} \mathrm{T}_{2} \mathrm{w}$ obrębie pewnych obszarów wiedzy (dotyczy to nie tylko wspomnianych relacji rodzinnych Mariusza Wilka, ale również usytuowania danej książki na konkretnym etapie pisarskiej drogi - znajdujące się na 4. stronie polskich okładek informacje

в самый раз для обложки будущей книги. Лес рогов образует на нем удивительную воздушную тропу, постепенно тающую в бледно-голубой мгле. На переднем плане оленьи морды и глаза еще различимы, а дальше - только холки, затылки и рога, рога - тропа рогов. Но ведь достаточно окрика (выстрела!), чтобы стадо в панике разбежалось, а тропа исчезла. Словно внезапно прерванный сон. Метафора моей книги? Разве не так я начинал эту экспедицию - полный надежд на встречу с настоящими саамами? Сначала я гонялся за деталями в поисках подтверждения прочитанному ранее - концепциям, стереотипам, бог знает чему еще. А со временем понял, что все это туманно, эфемерно и неуловимо” (Wilk 2014b: 97-98). 
o przygotowywanych częściach lub/i zdjęcia opublikowanych już tomów „Dziennika Północnego”);

- może być udaną próbą odwołania się do treści książki, może też - co z ubolewaniem stwierdziła Irina Adelgejm, tłumaczka utworów nie tylko Mariusza Wilka, ale i m.in. Gustawa Herliga-Grudzińskiego - wiązać się z książką jedynie bardzo powierzchownie, na zasadzie: $w$ tytule jest słowo pustynia, na obrazku też będzie pustynia ${ }^{11}$;

- nie musi przekreślać związku z ładunkiem znaczeniowym tekstu jako całości; zdecydowanie trudniejsze (szczególnie gdy mamy do czynienia z serią) jest oddanie konkretnych wytycznych (jak w przypadku zdjęcia renów w książce „Tropami rena”).

Poniżej, przechodząc od relacji okładka - wnętrze, poświęcę jeszcze kilka słów samemu wnętrzu książki, zwracając przy tym uwagę na trzy możliwe rozwiązania stosowane w przekładzie odnośnie do warstwy ilustracyjnej, będą to: 1) redukcja, 2) modyfikacja i 3) przeniesienie.

1) Redukcję paratekstów graficznych w tekście docelowym należy oceniać, biorąc pod uwagę rolę ilustracji w tekście wyjściowym, odpowiadając zatem na pytania:

- czy w oryginale jest to dodatkowy element utworu bardziej wpływający na emocje związane $z$ opisywanym przedmiotem/miejscem/bohaterem niż bezpośrednio ilustrujący tekst. Odpowiednim przykładem będzie tu pierwsze wydanie „Wilczego notesu” (słowo/obraz terytoria, 1998 r.), w którym odbitki pięknych czarno-białych fragmentów sołowieckiej przestrzeni zamkniętych w obiektywie przez Tomasza Kiznego ${ }^{12}$ zostały wklejone do książki. Sądzę, że dzięki nim obcowanie z zapiskami Wilka nabiera jeszcze bardziej osobistego charakteru.

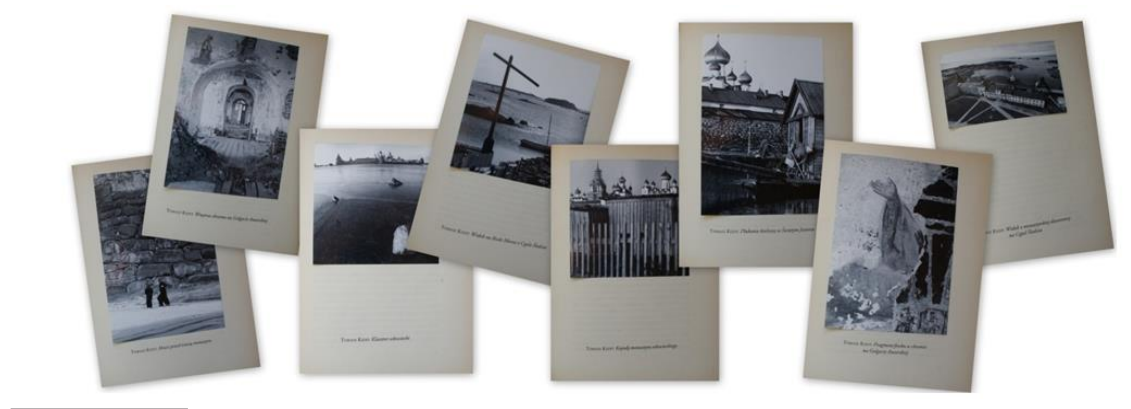

${ }^{11}$ Na podstawie rozmowy z tłumaczką (2007 r.).

${ }^{12}$ Więcej na temat autora m.in. na stronie: http://culture.pl/pl/tworca/tomasz-kizny (dostęp: 15.04.2019). 


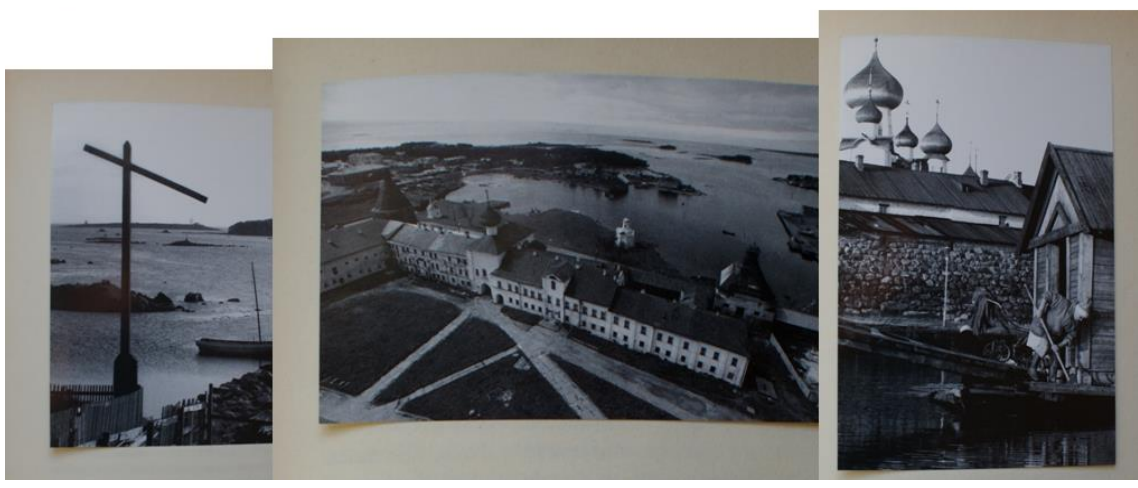

- Pomijając jednak rzadko spotykaną formę obecności zdjęć w tekście, co trzeba uznać za ogromny walor tegoż wydania, same fotografie choć ilustrują ów tekst, nie są z nim jednak nierozerwalnie związane. Są dodatkiem, nie zaś integralną częścią utworu, czego dowodem jest ich układ w książce (uzależniony nie od treści, a od graficznego porządku - zdjęcia pojawiają się mniej więcej co 30 stron) oraz ich brak w kolejnych publikacjach, co dotyczy nie tylko publikacji sygnowanej przez inne wydawnictwo (Noir Sur Blanc, 2007 r.), ale też reedycji przygotowanej przez słowo/obraz terytoria w roku 2003. W związku z powyższym (szczególnie zaś w związku z faktem, że tekstem źródłowym dla przekładu była wspomniana reedycja z 2003 roku) fotografii $\mathrm{w}$ tekście docelowym nie ma. Warto się zastanowić, czy traci na tym rosyjski odbiorca. Wydaje się, że nie, co też w pewnym stopniu potwierdzają słowa jednej z polskich czytelniczek, która zauważa: „proza Mariusza Wilka jest tak sugestywna, że nie potrzebuje żadnych uzupełnień" (dlatego ilustracje obejrzała po lekturze książki; zob. Eireann 2013) ${ }^{13}$;

${ }^{13}$ Temat fotografii w pierwszym wydaniu „Wilczego notesu” podniosły m.in. O. Kubińska i D. Żyłko, wypowiadając się o nich w następujący sposób: „Myśl marszczy się [...] przy odbiorze monochromatycznych fotografii Tomasza Kiznego, towarzyszących «Notesowi». Fotografie Kiznego, na pierwszy rzut oka piękne, statyczne, ukazują bezczasowość Rosji i rosyjskiego doświadczenia, po zastanowieniu wywołują niepewność. Wprawdzie geometria obrazu Płukanie bielizny w Świętym Jeziorze (s. 139) nieźle się tłumaczy (linie horyzontalne i wertykalne ubogaca, porządkuje ukośna oś kompozycji), a sama fotografia pokazuje detal (płukanie bielizny właśnie), czynność dziejącą się tu i teraz, jednak Widok na Białe Morze z Cypla Śledzia (s. 85) wzbudza pewne wątpliwości. Odbiorca zaczyna zastanawiać się, czy ten krzyż nad brzegiem morza, który jednocześnie z wyglądu przypomina szubienicę, nie jest zbyt nachalną ilustracją, nazbyt «oczekiwaną i pożądaną» syntezą tajemniczego kraju?” (Kubińska, Żyłko 1999: 183). 
- czy jest to ilustracja będąca odbiciem konkretnego fragmentu tekstu, bezpośrednio z nim związana, jak np. w przypadku fotografii umieszczonych w opowieści Huellego „Mercedes-Benz” (fotografia zajmuje zawsze kolejną stronę po przywołanym wspomnieniu, poniżej Huelle 2003: 82-82, 88-89);

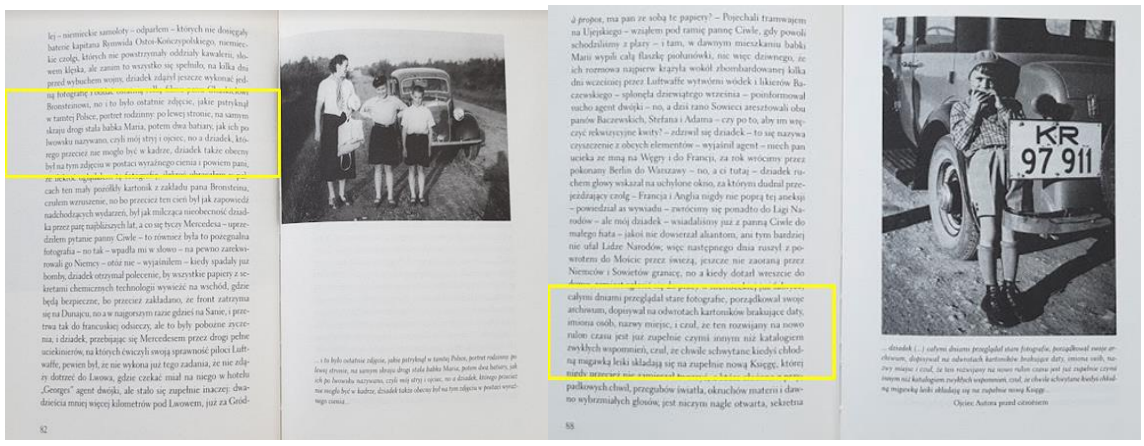

- czy wreszcie paratekst graficzny stanowi element konstrukcyjny tekstu, jak w przypadku m.in. „Małego księcia” (o czym pisała Joanna Górnikiewicz, zob. 2011) lub wspomnianych wcześniej „Przygód Erasta Fandorina”. Tu nawet aspekt finansowy, choć oczywiście niezmiernie istotny, nie powinien jednak wychodzić na pierwszy plan i skutkować usunięciem ilustracji. Niektóre treści bez paratekstu graficznego po prostu stają się niezrozumiałe bądź zrozumiałe w mniejszym stopniu. Marta Kaźmierczak podaje przykład zaczerpnięty z książki Akunina „Весь мир театр” (pol. „Świat jest teatrem”). $\mathrm{W}$ oryginale widnieje $\mathrm{w}$ niej m.in. ilustracja przedstawiająca afisz, padają też słowa (tu przytoczone z przekładu):

Fandorin, tak jak zamierzał, najpierw podszedł do afisza, by zapoznać się ze składem trupy. [...] tytuł przedstawienia ostatecznie popsuł humor widzowi wbrew woli. Fandorin ponuro patrzył na wytworny plakat $\mathrm{z}$ winietą, myśląc, że wieczór będzie najprawdopodobniej jeszcze bardziej męczący, niż się spodziewał (Akunin 2012: 24).

Odbiorca powyższego cytatu nie wie, jaka sztuka wywołała takie emocje u bohatera.

Pominięcie afisza [w tekście docelowym] wprowadza pewien kognitywny dysonans w trakcie lektury: tam, gdzie w tekście pojawiają się nawiązania do treści afisza [...] 
powstaje [w przekładzie] wrażenie eliptyczności, braku spójności (Kaźmierczak 2016: 73).

Gubią się nie tylko informacje o cenie, braku przerwy, ale znika też, jak podkreśla Kaźmierczak, inna ważna wskazówka, a mianowicie lista obsady widniejąca na afiszu, która jest jednocześnie spisem bohaterów rozpoczynającej się w obrębie tego tomu historii.

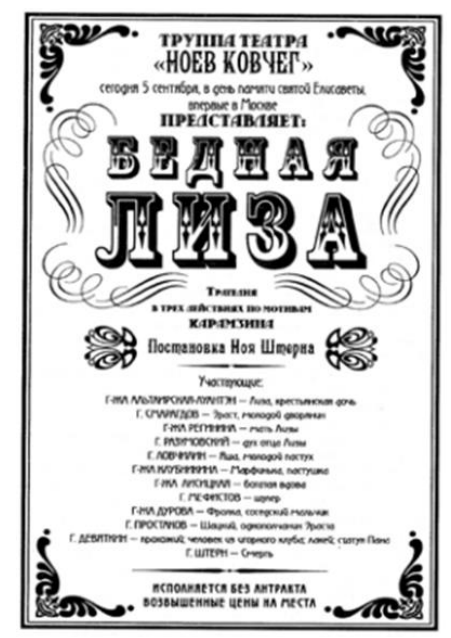

Fot. za: Kaźmierczak 2016: 73.

2) Kolejną procedurą jest modyfikacja. Już na początku trzeba jednak zaznaczyć, że zmiana koncepcji graficznej wnętrza książki powinna być przeprowadzana w bardzo rozważny sposób. Anna Bednarczyk podkreśla:

jeśli pierwowzory [tj. oryginały tekstów literackich] były zaopatrzone w ilustracje, które utrwaliły się w świadomości czytelników, lepiej nie zastępować ich nowymi. Na odbiorcę działa zwykle magia pierwowzoru (przyzwyczajenie) (Bednarczyk 2008: 72).

Jak pisze Joanna Górnikiewicz, „wszelkie próby przełamania czytelniczych przyzwyczajeń są z pewnością bardzo ryzykowne, jednak nie muszą być z góry skazane na niepowodzenie" (2011: 101). Ta ostatnia refleksja odnosi się między innymi do „Małego księcia” (KAW, 1994 /zob. poniżej il. 2/) z nową (tj. nieautorską) szatą graficzną, zawierającą odwołania do realiów końca XX wieku; szatą, która może - jak zaznacza wydawca - „zaskoczyć, 
zirytować”, ale może też rozbawić, a nawet „zaczarować” (zob. ibid.: 100) ${ }^{14}$. O ryzyku odejścia od oryginalnych rysunków i potrzebie usprawiedliwiania podjętego kroku świadczyć też może opis dotyczący wydania tegoż tekstu z 2018 roku /zob. poniżej il. 3/: „Ponadczasowa historia z pięknymi ilustracjami autorstwa Pawła Pawlaka, które pozwalają na nowo odkryć emocje związane z opowieścią i jej symbolikę" (Saint-Exupery 2018).
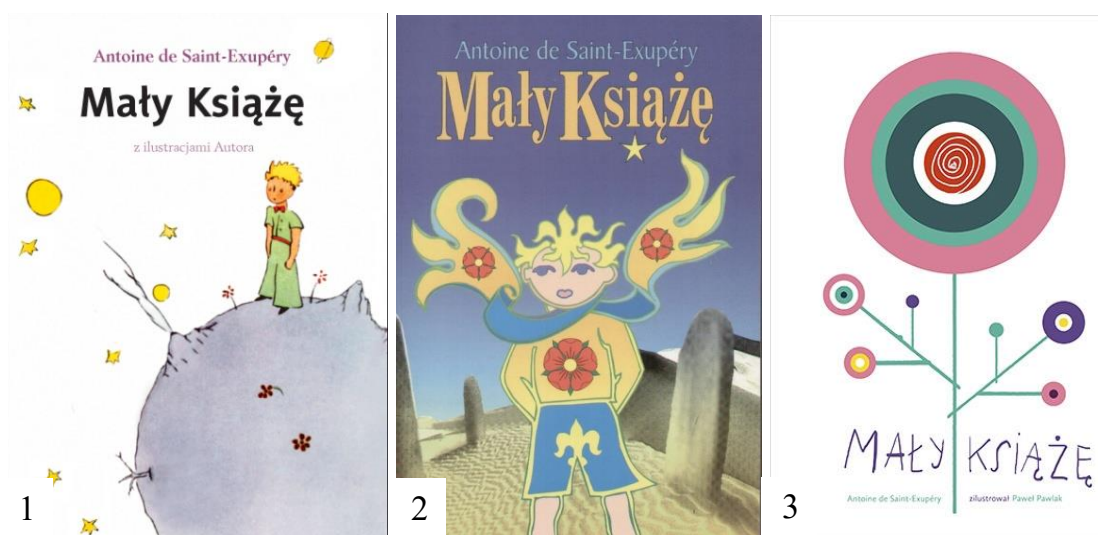

Antoine de Saint-Exupery, Mały książę: /1/ il. autorskie (https://www.swiatksiazki.pl/ksiazki-proza-3225/maly-ksiaze-6202919-ksiazka.html); /2/ il. Tadeusz Gajl (http://katalog. mbp.opole.pl/sowacgi.php?KatID=0\&typ=record\&001=OP\%20M10069699;/3/ il. Pawel Pawlak, (https://www.znak.com.pl/ksiazka/maly-ksiaze-nowe-ilustracje-antoine-de-saintexupery-119846; dostęp: 15.04.2019).

3) Wydaje się więc, że najlepszym rozwiązaniem będzie trzecia możliwość - przeniesienie, tj. zachowanie koncepcji graficznej oryginału. $Z$ doświadczenia wiemy, że jednak nie zawsze tak jest, co szczególnie uwidacznia się, gdy rozpatrywany element graficzny zawiera element werbalny, np. dla osób nieznających cyrylicy pozostanie nieczytelna ilustracja, w skład której wchodzi podpis (choćby nazwa mikrotoponimu). Odnotowuje to Marta Kaźmierczak w kontekście ryciny zamieszczonej w „Nefrytowym różańcu” Akunina, dwunastej części serii o Eraście Fandorinie.

${ }^{14}$ Należy za Joanną Górnikiewicz dodać, że wydawca zatroszczył się poprzez wprowadzenie pewnych zmian w treści o harmonię między tekstem a nowym obrazem (2011: 100). 


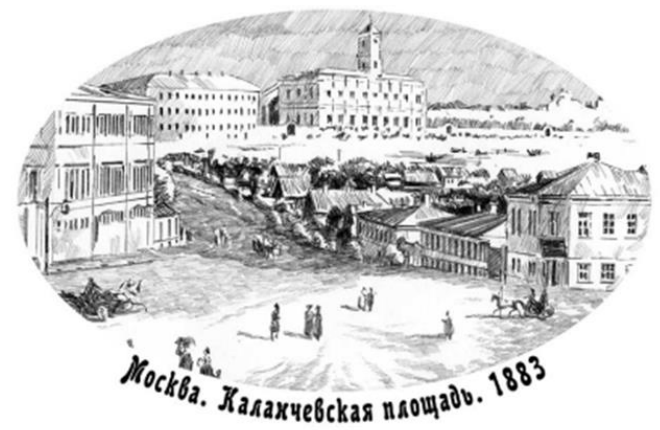

Fot. za: Kaźmierczak 2016: 71.

„Brak ingerencji typograficznej - konstatuje badaczka - można by uzasadnić chęcią jak najdokładniejszego zachowania kolorytu lokalnego oryginału, lecz prawdopodobniejsze wydaje się, że po prostu nie zadbano o potrzeby kognitywne polskiego czytelnika" (Kaźmierczak 2016: 71). Oczywiście, modyfikacja elementu graficznego nie może odbywać się kosztem nieposzanowania praw autorskich, zdaje się jednak, że w powyższej sytuacji wystarczyłoby dodanie pod elementem graficznym nazwy w języku polskim bez konieczności wprowadzania zmian w jego obrębie. W kolejnym przykładzie brak modyfikacji wywołał nie tyle (albo nie tylko) niezrozumienie, co irytację, dotyczy to mapy dołączonej do książki „Lotem gęsi” Mariusza Wilka przeniesionej bez zmian z $\mathrm{T}_{1}$ do $\mathrm{T}_{2}$. Nazwy zaznaczone na mapie Labradoru to mieszanka składająca się z trzech języków - angielskiego i francuskiego (języki urzędowe Kanady) oraz polskiego.

Карта Канады. Вроде самая понятная и логичная. Даже нарисован маршрут путешествия. Но на каком языке карта? Половина названий на французском языке, половина - на английском. Вроде для Канады даже логично. Ho Rzeka Swietego Wawrzynca - это вообще откуда?"15 (ValSi 2014).

Ponownie trzeba zapytać o możliwość modyfikacji, czyli szansę zastąpienia polskich nazw na mapie nazwami rosyjskimi; zapytać, czy jest to zdjęcie mapy, z której autor korzystał podczas podróży i wprowadził do książki jako pewną pamiątkę dokumentującą tę podróż, czy jest to tylko schemat przed-

15 „Mapa Kanady. Wydaje się najbardziej zrozumiała i logiczna. Nawet zaznaczono trasę podróży. Ale w jakim języku jest mapa? Połowa nazw po francusku, połowa po angielsku. W przypadku Kanady - to logiczne. Ale skąd się wzięła Rzeka Swietego Wawrzynca?” [tłum. M.K] 
stawiający pokonaną trasę. $\mathrm{W}$ omawianym przypadku mamy do czynienia $\mathrm{z}$ drugą opcją, ponadto $\mathrm{w}$ książce są jeszcze inne mapy, w tym plan Pietrozawodska, który w oryginale został przystosowany dla polskiego odbiorcy (polskie nazwy; zob. 2012a: 20 -21), w przekładzie - dla docelowego (nazwy rosyjskie; zob. 2014b: $20-21$ ). Wydaje się więc, że podobny zabieg można było przeprowadzić i w przypadku mapy Labradoru, czego niestety zaniechano, wywołując taką, a nie inną opinię recenzentki.

Reasumując, można by za pośrednictwem tłumaczy zasugerować wydawcom zwrócenie większej uwagi na przestrzeń skrzydełek okładki bądź jej wewnętrznych stron (2. i 3.), które warto byłoby wykorzystać na wyrównanie różnic powstających przy zmianie koncepcji graficznej okładek $\mathrm{T}_{1} \mathrm{i} \mathrm{T}_{2}$, w przypadku zaś paratekstu graficznego umieszczonego wewnątrz książki zastanowienia się: „kiedy [musi on] być, a kiedy [może go] nie być”' ${ }^{16}$, a jeśli musi być - to czy dokładnie w takiej samej postaci.

\section{Literatura}

Akunin B., 2012, Świat jest teatrem, tłum. O. Morańska, Warszawa.

Akunin Chkhartishvili, 2017, Vingt ans après, https://www.facebook.com/ borisakunin/posts/908613042622043/ (dostęp: 15.04.2019).

Bednarczyk A., 2008, W poszukiwaniu dominanty translatorskiej, Warszawa. Eireann, 2013, Mariusz Wilk: Wilczy notes (recenzja), 4.05.2013, http://ksiazkomania-eireann.blogspot.com/2013/05/wilczy-notes-mariusz-wilk. html (dostęp: 15.04.2019).

Górnikiewicz J., 2011, Paratekst niewerbalny w „Małym księciu” Antoine’a de Saint-Exupéry’ego i w jego polskich wydaniach, „Między Oryginałem a Przekładem", 17, s. 85-104.

Hrehorowicz U., 1997, Przypisy thumacza: to be or not to be, „Między Oryginałem a Przekładem", 3, s. 110-116.

Huelle P., 2003, Mercedes-Benz. Z listów do Hrabala, Kraków.

Jastrzębska A. S., 2011, Egzotyka czy popkultura? Parateksty przekładów najnowszej powieści kryminalnej z Ameryki Łacińskiej, „Między Oryginałem a Przekładem", 17, s. 231-242.

Kaźmierczak M., 2016, Tekst, paratekst, przesunięcia interpretacyjne w polskich wydaniach „Przygód Fandorina” (część 1: parateksty graficzne), „Przegląd Rusycystyczny”, 1(153), s. 61-80.

${ }^{16}$ Słowa „kiedy być, a kiedy nie być” zamykają rozważania Uty Hrehorowicz (1997: 116) na temat obecności przypisów w dziele literackim. 
Krajewska M., 2017, Oswoić słowo. Komentarze w północnych książkach Mariusza Wilka, Torun.

Kubińska O., Żyłko D., 1999, Notatki na marginesie „Wilczego notesu”, „Kresy", 37, s. 181-184.

Leonardo komp'yuterom by ne prenebreg, 2009, Internet-zhurnal „Litsey", 26.02.2009, http://gazeta-licey.ru/news/chronicle/808-leonardo-kompyuterom-by-ne-prenebreg (dostęp: 15.04.2019) [Леонардо компьютером бы не пренебрег, 2009, Интернет-журнал «Лицей», 26.02.2009, http://gazeta-licey.ru/news/chronicle/808-leonardo-kompyuterom-by-ne-prenebreg].

Loewe I., 2007, Gatunki paratekstowe w komunikacji medialnej, Wydawnictwo UŚ, Katowice 2007.

Saint-Exupery A., 2018, Mały Książę (nowe ilustracje), https://www. znak.com.pl/ksiazka/maly-ksiaze-nowe-ilustracje-antoine-de-saintexupery-119846 (dostęp: 15.04.2019).

Skibińska E., 2011, Konwicki z okładki. O wydawniczych paratekstach francuskich przekładów powieści Tadeusza Konwickiego, „Między Oryginałem a Przekładem", 17, s. 179-192.

ValSi, 2014, Mariusz Wilk: Putem dikogo gusya (recenzja), 13.04.2014, https://www.livelib.ru/review/357582-putem-dikogo-gusya-mariush-vilk (dostęp: 15.04.2019).

Wilk M., 1998, Wilczy notes, Gdańsk.

Wilk M., 2005, Wołoka, Kraków.

Wilk M., 2006, Dom nad Oniego, Warszawa.

Wilk M., 2007a, Tropami rena, Warszawa.

Wilk M., 2007b, Wilczy notes, Warszawa.

Wilk M., 2008, Volok, tłum. I.Adel'geym, Sankt-Peterburg. [Вильк M., 2008, Волок, пер. И. Адельгейм, Санкт-Петербург].

Wilk M., 2010, Tropami severnogo olenya, tłum. I.Adel'geym, Sankt-Peterburg. [Вильк М., 2010, Тропами северного оленя, пер. И. Адельгейм, Санкт-Петербург].

Wilk M., 2012a, Lotem gęsi, Waraszawa.

Wilk M., 2012b, Dom nad Onego, tłum. I.Adel'geym, Sankt-Peterburg. [Вильк М., Дом над Онего, пер. И. Адельгейм, Санкт-Петербург]. Wilk M., 2014a, Dom włóczęgi, Warszawa.

Wilk M., 2014b, Putem dikogo gusya, tłum. I.Adel'geym, Sankt-Peterburg. [Вильк М., 2014b, Путем дикого гуся, пер. И. Адельгейм, СанктПетербург].

Wilk M., 2015, Dom stranstviy, tłum. I. Adel'geym, Sankt-Peterburg. [Вильк М., 2015, Дом странствий, пер. И. Адельгейм, Санкт-Петербург]. 
Zhemoytelite Ya., Nakonechnyy V., 2012, Tvorcheskoye bytiye Vitaliya Nakonechnogo(interv'yu s V. Nakonechnym), http://knk.karelia.ru/2012/04/ tvorcheskoe-bitie-vitalija-nakonechnogo.html (dostęp: 15.04.2019). [Жемойтелите Я., Наконечный В., 2012, Творческое бытие Виталия Наконечного (интервью с В. Наконечным), Коренные народы Карелии, http://knk.karelia.ru/2012/04/tvorcheskoe-bitie-vitalija-nakonechnogo.html].

\section{From cover to cover: paratexts from the perspective of the original and translation Summary}

The paper deals with graphical paratexts, and this issue is considered from the perspective of the original and translation. The first part of the paper focuses on the covers of original texts and the consequences related to different concepts of the graphic layout of the target texts, including varying intended recipients and the need to introduce additional translator's footnotes and comments. In the second part, the role of illustrations in the original text is discussed, because it determines the assessment of the procedures applied - reduction, modification and transfer.

Keywords: paratext, original, target text, translation, graphic design, cover, recipient, translator's footnote

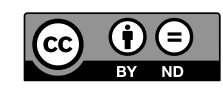

